2010

\title{
Christian Realism and Immigration Reform
}

Victor C. Romero

Penn State Law

Follow this and additional works at: http://elibrary.law.psu.edu/fac_works

Part of the Christianity Commons, Ethics in Religion Commons, and the Immigration Law Commons

\section{Recommended Citation}

Victor C. Romero, Christian Realism and Immigration Reform, 7 U. St. Thomas L.J. 310 (2010).

This Article is brought to you for free and open access by the Faculty Works at Penn State Law eLibrary. It has been accepted for inclusion in Journal Articles by an authorized administrator of Penn State Law eLibrary. For more information, please contact ram6023@psu.edu. 


\title{
Article \\ Christian Realism and IMMIGRATION REFORM
}

\author{
VICTOR C. ROMERO*
}

\begin{abstract}
Drawing upon President Barack Obama's admiration of Reinhold Niebuhr's work, this essay outlines a Protestant, Christian realist approach toward immigration policy, with specific focus on the role of the executive in providing providential leadership. Embracing realism in its political, moral, and theological dimensions, Christian realism offers a pragmatic, yet optimistic, alternative to secular liberalism's faith in reason by striving instead to adhere to God's guidance on matters, taking into account the fundamentally flawed nature of man. The specific policy prescriptions described here mirror the twin virtues of Christian realism by promoting the hope in pursuit of the peaceable kingdom and the humility to acknowledge the fallibility of man in crafting the less-than-perfect, penultimate answer. Opportunities for exercising effective executive leadership will be discussed, from negotiating the proper role of states and localities to the promotion of comprehensive immigration reform, preferring immigrant integration to stringent law enforcement as the better means to further hospitality to the stranger.

During his candidacy for President, Barack Obama was interviewed by New York Times reporter David Brooks about foreign aid to Africa. During a break in the interview, Brooks asked for Obama's thoughts on the Christian realist thinker Reinhold Niebuhr. Obama enthusiastically affirmed that

* Professor of Law \& Maureen B. Cavanaugh Distinguished Faculty Scholar, Penn State University; vcr1@psu.edu. Thanks to Jamie Colburn, Rob Gatter, Won Kidane, Zak Kramer, Maria Pabón-López, Ediberto Román, Steve Ross, Michael Scaperlanda, Alexis Snyder, and Rob Vischer for insightful comments and conversation on earlier drafts. A version of this paper was presented at the LatCrit XIV conference, the Murphy Institute's symposium on Christian Realism, and as part of the Penn State Law Review's "Scholarly Dialogues" series. Thanks to all the participants at those events for their comments. Thanks also to Dean Phil McConnaughay for his support of this and all my work, and to my family in the Philippines and Singapore for their grace and example. Most important, thanks to my wife, Corie, and my children, Ryan, Julia, and Matthew, for their constant love and affection. All errors that remain are mine alone.
\end{abstract}


Niebuhr was one of his "favorite philosophers," highlighting the following lesson:

I take away . . . the compelling idea that there's serious evil in the world, and hardship and pain. And we should be humble and modest in our belief we can eliminate those things. But we shouldn't use that as an excuse for cynicism and inaction. I take away ... the sense we have to make these efforts knowing they are hard, and not swinging from naïve idealism to bitter realism. ${ }^{1}$

This essay springs from this brief exchange between Obama and Brooks, focusing on Christian realism (the term often used to describe Niebuhr's philosophy), and how it might help guide the executive in the formulation of a just immigration policy. In his response to Brooks, Obama succinctly captured both the "hope" and "humility" present in Christian realism. Christian realists "hope" that mankind will aim to pursue human flourishing in the service of God's will, even as we face, with "humility," the reality that self-interested humans often opt for political gain over civic virtue.

The remainder of the essay unfolds in five parts. Part I will further explore the meaning of Christian realism's message of "hope" and "humility," referencing its political, moral, and theological dimensions as these relate to the philosophy of Niebuhr and other leading thinkers and activists. Given his admiration of Niebuhr and his centrist approach to politics, might Obama benefit from Christian realism's insights as he tackles the particularly thorny and contentious issue of reforming U.S. immigration policy?

Parts II and III focus on the "hope" and "humility" inherent in a Christian realist approach to immigration policy. Part II examines the Christian ideal of "hope" by exploring the main passages in both the Old and New Testaments on the treatment of "aliens." The goal here is to try to discern what God might expect of us as we seek to bring a theological perspective to the pursuit of the common good. As is true today, biblical writers accepted the reality of different nations and peoples, and yet strove to ensure fair treatment to those who were noncitizens. In the New Testament in particular, Jesus Christ challenges believers to extend the definition of neighbor $^{2}$ and to attend to the needs of the least of these. ${ }^{3}$ Part III then turns to the theme of "humility" by focusing on the realities that constrain leadership in immigration policy today. A generally centrist Congress and electorate appear to have little appetite for pro-immigrant rights policies without more stringent guarantees of effective interior and exterior enforcement. Furthermore, states and local governments demand to have a role in what

1. David Brooks, Obama, Gospel and Verse, N.Y. Times, Apr. 26, 2007, available at http:// select.nytimes.com/2007/04/26/opinion/26brooks.html.

2. Luke 10:25-37 (New International Version).

3. Matthew 25:31-46 (New International Version). 
has traditionally been the province of federal authority. Finally, this (over)emphasis on enforcement ahead of integration perpetuates the divide between citizen and noncitizen, leading to some unfortunate yet foreseeable consequences.

Part IV suggests a Christian realist alternative to the current immigration enforcement regime, one that seeks to balance the biblical ideals in Part II against the realities of current politics in Part III. From reconfiguring the rhetoric of comprehensive immigration reform to mediating the role of states and localities, immigrant-friendly alternatives focusing more on integration than enforcement will be explored.

Part V concludes this essay with an appeal that is more "Christian" than "realist." If our ultimate goal is to mirror God's kingdom here on earth, then Christian leaders should take seriously the notion that a more open border policy best approximates the ideal City of God than settling for compromises based on man-made values, fears, and concerns.

\section{Christian Realism, the Obama Administration, AND IMMIGRATION POLICY}

Being an avowed politically centrist President is tough. Your supporters don't think you're liberal enough; your critics dismiss you as a socialist. Claiming to be a practicing Christian while maintaining religious neutrality in administration is arguably tougher. You either risk being ridiculed for your blind adherence to mythology or you are chastised for not vigorously implementing a faith-based agenda (within constitutional bounds, of course) ${ }^{4}$ Moreover, inheriting the presidency during rough economic times raises the stakes even higher. Stewarding a nation's domestic resources while simultaneously confronting serious international challenges, crafting a coherent leadership strategy in the face of daunting and diverse priorities, and above all, providing hope in a time of uncertainty, seem a pipe dream. Barack Obama wants to be that centrist President who happens also to be a Christian, earnestly reaching across the partisan divide in an attempt to move the United States forward on a number of fronts, promising an ambitious domestic agenda in energy, education, and the economy, while simultaneously struggling to redeem America's tarnished image abroad following years of often unilateral, militant action.

4. Some might be concerned that $\mathrm{I}$ am advocating that the President impose his religious views on a pluralistic, secular nation. None of the proposals here are much different from those advanced by secular advocates. In an effort to continue to expand the scope of our political discourse, my modest hope is to provide a Christian realist perspective on the issue of immigration reform and executive leadership, not to advance any particular religious agenda. See generally Stephen L. Carter, The Culture of Disbelief: How American law and Politics Trivialize Religious Devotion 68 (1994) ("[I]f the principle value of religion to a democratic polity is its ability to preach resistance, it is difficult to see any gain to religion from the unswerving effort to take control of the apparatus of the state."). 
For those who study U.S. immigration policy, President Obama's campaign promises of comprehensive immigration reform and renewed leadership in balancing adherence to the rule of law against compassion for the plight of migrants offered hope after we witnessed increasingly stringent restrictions on immigrant rights, especially after $9 / 11$. Perhaps overshadowed by other priorities, immigration reform has not made it to the table yet this term; while President Obama has promised to comprehensively study the issue during this, his second year in office, most of the rhetoric coming out of his administration has been to echo his predecessor's emphasis on interior and exterior enforcement first. ${ }^{5}$

This essay hopes to offer some thoughts on executive leadership in immigration reform ${ }^{6}$ through the lens of Christian realism, a worldview that realistically acknowledges the role of self-interest and power in political relations, but simultaneously hopes and aspires to do God's will on earth. ${ }^{7}$ During his campaign, President Obama cited the work of Reinhold Niebuhr, the prominent 20th century Protestant ${ }^{8}$ theologian, as particularly influential

5. In fact, Obama recently announced he would delay focusing on any comprehensive immigration reform until 2010, after Congress completes its work on healthcare, energy, and the economy. See, e.g., Ginger Thompson \& Marc Lacey, Obama Sets Immigration Changes for 2010, N.Y. Times, Aug. 11, 2009, at A6. Holding the President's feet to the fire on comprehensive immigration reform, the ImmigrationProf Blog runs a regular headline titled, "Obama on Immigration: Enforcement Now, Enforcement Forever?" reflecting the view of "[a] number of immigration advocates - as well as some law professors - [who] are beginning to worry about the future of true immigration reform in the Obama administration." Posting of Kevin R. Johnson, to ImmigrationProf Blog, http://lawprofessors.typepad.com/immigration/2009/08/obama-on-immigration-enforcement-now-enforcement-forever.html (Aug. 2, 2009). Indeed, Michael Olivas recently described the current administration's approach as "literally . . . the worst of all worlds." Julia Preston, Firm Stance on Illegal Immigrants Remains Policy, N.Y. Trmes, Aug. 4, 2009, at A14, available at http://www.nytimes.com/2009/08/04/us/politics/04immig.html. This sense that enforcement has proceeded unabated has been supported by empirical evidence. See Transactional Records Access Clearinghouse, Immigration Enforcement Under Obama Returns to Bush-Era Highs, July 21, 2009, http://trac.syr.edu/whatsnew/email.090721.html.

6. For a recent perspective on the President's power over immigration law vis-à-vis the Congress, see generally Adam B. Cox \& Cristina M. Rodríguez, The President and Immigration Law, 119 YALE L.J. 458 (2009).

7. Much of the legal academic writing/blogging on immigration issues and religion has come from a Catholic perspective. See, e.g., Michael A. Scaperlanda, Immigration Law: A Catholic Christian Perspective on Immigration Justice, in Recovering Self-Evment Truths: Catholic Perspectives on American Law 292 (Michael A. Scaperlanda \& Teresa S. Collett, eds., 2007); Michele R. Pistone \& John J. Hoeffner, Stepping out of the Brain Drain: Applying Catholic Social Teaching IN a New Era of Migration (2007); Mary Ann Glendon, Principled Immigration, FIRST THINGs, June-July 2006, at 23. Other prominent writings have been more ecumenically Christian, but not focused on immigration. See, e.g., Christian Perspectives on Legal Thought (Michael W. McConnell, Robert F. Cochran, Jr. \& Angela C. Carmella, eds. 2001). One recent exception is a book chapter on immigration from an evangelical Christian congressional staffer. See James R. Edwards, Jr., A Biblical Perspective on Immigration Policy, in Debating Immigration 46 (Carol M. Swain ed., 2008).

8. Protestantism being what it is, Christian realism is not subject to a single definition, policy statement, or interpretation. In contrast, the Catechism of the Catholic Church of the U.S.A. provides an official view of a nation's obligations to noncitizens, for instance: "[paragraph] 2241. The more prosperous nations are obliged, to the extent they are able, to welcome the foreigner in 
to his way of thinking. ${ }^{9}$ The term "Christian realism" has come to define the philosophy of Niebuhr and his fellow travelers. In his influential essay on Augustine's City of God, Niebuhr notes that whereas classical political and moral realism correctly acknowledge man's self-interest and desire for power, Augustine's (Christian) realism roots this selfishness in the biblical divide between God's infallibility and man's finitude. ${ }^{10}$ Because of man's sinfulness, Christian realists do not rely solely on man-made inventionsscience, reason, or psychology, for instance-to achieve human perfection; rather, while acknowledging that these tools are important gifts from God, Christian realists nonetheless believe that only God can fulfill humanity's deepest needs. ${ }^{11}$

Christian realists, therefore, reject $^{12}$ both classical liberalism and utopian idealism-liberalism because it believes that advances in human knowledge and technology will cure all evils, and utopianism because it believes humans have the power to save themselves from themselves. In the tradition of the Hebrew prophets and as revealed in the person of Jesus Christ, Christian realists doubt man's ability to achieve perfection, reflecting the classical belief in human selfishness. Yet, rather than wallowing in despair, Christian realists value the pursuit of the common good (peace and justice) as much as the liberal or the idealist; their disagreement arises from their belief that only God can save man from his inherent sinfulness. Dietrich Bonhoeffer, the German clergyman and a student of Niebuhr, describes this second-best goal as the "penultimate." 13 As social ethicist Robin Lovin argues, "[c]oncentration on the penultimate requires, accord-

search of the security and the means of livelihood which he cannot find in his country of origin. Public authorities should see to it that the natural right is respected that places a guest under the protection of those who receive him. Political authorities, for the sake of the common good for which they are responsible, may make the exercise of the right to immigrate subject to various juridical conditions, especially with regard to the immigrants' duties toward their country of adoption. Immigrants are obliged to respect with gratitude the material and spiritual heritage of the country that receives them, to obey its laws and to assist in carrying civic burdens." CATECHISM OF the Catholic Church: Modifications from the Edrrio Typica No. 2241 (2d ed., U.S. Catholic Conf. 1997).

9. See generally Brooks, supra note 1 .

10. Reinhold Niebuhr, Augustine's Political Realism, in The Essential Rennhold Niebuhr: Selected Essays ANd Addresses, 123-41 (Robert McAfee Brown ed., 1986). For more on Christian realism, see also Reinhold Niebuhr, Christian Realism and Political Problems (1953); Heather A. Warren, Theologians of a New World Order: Reinhold Niebuhr and tHE Christian Realists 1920-1948 (1997).

11. It may also be true that man's conception of "human flourishing" may not match God's. For instance, because of our inherent sinfulness, it may be that a certain amount of suffering in this world is necessary, at least on a personal level (and perhaps, when multiplied manifold, at a societal level) to help correct and instruct, but it is unlikely that the Christian God in the person of Jesus enjoys human suffering for its own sake. For example, Jesus wept upon discovering Lazarus dead. John 11:35 (New International Version).

12. This is not to claim the superiority of Christian realism over classical liberalism or utopian idealism, but simply to distinguish the former from the latter.

13. Robin W. Lovin, Christian Realism and the New Realities 3 (2008). 
ing to Bonhoeffer, a rejection both of the radical politics that is willing to destroy anything and everything for the sake of ultimate truth and of the compromises that, by suspending judgment until ultimate truth is fully present, slip by degrees into relativism."14 In an effort to seek the good of all, man's task is to strive, imperfectly, to do God's (perfect) will, which is the best that man can expect on this side of the Fall.

In Niebuhr's day, these ideas most prominently bore fruit in influencing international political thought, centering on the rise of Nazism and Soviet-style communism as threats to Western democracies, as well as the proper contours of a "just war" (with World War II as the contemplated prototype). Studying under Niebuhr, the cleric Bonhoeffer could do no less than oppose the Nazi regime as immoral, leading to his ultimate martyrdom. ${ }^{15}$ Christian realism also influenced the course of the domestic civil rights movement in the United States. Citing Niebuhr's work, Martin Luther King, Jr., though initially optimistic that reason would prevail, was ultimately persuaded by Niebuhr of man's inherent sinfulness in all things, thus helping King properly orient his resistance against white oppression, albeit in a peaceful way. ${ }^{16}$

Reflecting on Niebuhr's legacy, social ethicist Lovin argues that Christian realists embrace three facets of "realism" in its political, moral, and theological dimensions, all held together in dynamic tension, often overlapping with one dimension qualifying the others, not always in logical fashion. "Political realism analyzes political choices in terms of self-interest and power." ${ }^{17}$ Reminiscent of Machiavelli, Hume, and classical liberal theorists, political realism aims to describe personal and collective behavior as it isself-interested and desirous of power-rather than as it should be. As one commentator describes it, "[r]ealism involves a rejection of 'ideal theory,'

14. Id. at 5 .

15. See, e.g., David N. Field, Dietrich Bonhoeffer, in Empire ANd the Christian Tradition 389, 389 (Don H. Compier, Pui-lan Kowk \& Joerg Rieger eds., 2007) ("With the rise of the Third Reich [Bonhoeffer] became an active opponent of Nazism in the church. After the outbreak of World War II, Bonhoeffer became involved in a plot to assassinate Hitler and overthrow the Nazi regime."); Theodore S. Hamerow, ON the Road to the Wolf's Lair: German Resistance to HITLER 386 (1997) ("Bonhoeffer, who had been an opponent of the Nazi regime from the outset, was arrested in the spring of 1943.").

16. See Davison M. Douglas, Reinhold Niebuhr (1892-1971), in The Teachings of Modern Christianity on Law, Politics, and Human Nature 412, 432 (John Witte Jr. \& Frank S. Alexander eds., 2006) (noting that, while King embraced Niebuhr's reminder that men were sinful in all things, he did not follow Niebuhr's call to reject pacifism); see also ReINHOLd NIEBUHR, Moral Man and Immoral Society: A Study in Ethics and Politics 253 (Westminster John Knox Press 2001) (1932) ("However large the number of individual white men who do and who will identify themselves completely with the Negro cause, the white race in America will not admit the Negro to equal rights if it is not forced to do so.') and David L. ChappelL, A Stone OF Hope: Prophetic Religion and the Death of Jim Crow 3 (2004) ("The black movement's nonviolent soldiers were driven not by modern liberal faith in human reason, but by older, seemingly more durable prejudices and superstitions that were rooted in Christian and Jewish myth.").

17. Lovin, supra note 13 , at 6 (emphasis omitted). 
which sets aside or abstracts from the constraints of the real world in working out the implications of ideal principles." ${ }^{18}$ Political realists are skeptical of claims of benign motivation, seeing through to the interests satisfied by the attainment of certain goals. ${ }^{19}$ Hence, the invasion of a theocratic nation by a democratic one, though ostensibly for the purpose of liberation, might be viewed by the political realist as motivated, in truth, by imperialism.

"Moral realism holds that our moral rules, ideals, and virtues reflect durable features of human nature that really exist, apart from the religious traditions, moral theories, and accumulated practical wisdom on which we draw to talk about them." 20 The moral realist, therefore, eschews cultural relativism, even if she is unsure whether the moral position she espousessay by using God's gifts of reason and experience-is the truth. Hence, "[a] moral realist is likely to be a 'fallibilist,' holding that moral realities can be known, but that any particular claim to moral knowledge may prove to be false, so that all such claims are in constant need of testing and correction." ${ }^{21}$ Such an approach infuses moral realism with a necessary degree of humility.

Still, the moral realist goes beyond mere acceptance of self-interest described by the political realist by appealing to ideal conditions for human flourishing, acknowledging the limits of human nature. Thus, the moral realist warns against self-interested behavior that does not advance the common good, arguing that only interests that fully account for the realities of human nature-both selfish and selfless-will survive in the long run. ${ }^{22}$ Moral realism and political realism act as checks on each other: While each is committed to realistically analyzing personal and collective choices as they are, political realism focuses on self-interest and power, whereas moral realism attends to both the limits of human nature and the goal of promoting human flourishing. Returning to the invasion example, a moral realist would want to know whether any invasion might be justified on higher

18. Frederick G. Whelan, Hume and Machiavelli: Political Realism and Liberal THоught 42 (2004). For an interesting discussion of the significant influence of western liberal thought on U.S. citizenship policy, see Ediberto Román, CITIZENSHIP AND ITS ExClusions: A Classical, Constitutional, and Critical Race Critique (forthcoming 2010).

19. Lovin, supra note 13, at 7 ("To be 'realistic' in this context means having a keen eye for all the interests that are actually at work in a political situation, thinking clearly about how they relate to one another, and looking beyond rhetoric, proclamations, one's own moral judgments, and other people's ideologies to determine what is actually driving choices and strategies.").

20. Id. at 8 .

21. Id. at 10 .

22. Id. at 8 ("A moral realist will qualify the political realist's immediate, concrete focus on power and interests by adding that interests which are incompatible with the conditions for human flourishing or which undermine the communities that sustain those conditions are interests which, sooner or later, will lose out to other interests which have a more realistic grasp of the requirements of human nature."). 
moral grounds (preemptive self-defense?) apart from the particular selfish interests that might underlie the action. ${ }^{23}$

Theological realism posits the existence of the divine that is a reality beyond the world's concerns about self-interest and human flourishing. "The reality of God stands beyond both the world that is susceptible to strategy and power and the enduring realities of human nature."24 Just as moral realists believe in a morality apart from our beliefs about it, so too with God: theological realists believe that God's existence is a reality apart from our subjective views. While some might recoil at such a robust claim, theological realists should display the same humility that characterizes moral realism, for no one knows for certain whether God exists. Like moral realists, theological realists reject relativism in favor of truth, while acknowledging human finitude in the face of the Infinite. For Christians, theological realism "culminates in Jesus Christ, who makes this divine reality present in the world, reveals God's judgment on it, and finally redeems it for God's own purposes." 25 Looking to Christ's example on earth, the theological realist puts ultimate faith in God rather than man, but still aspires to do God's will, and not his own. As applied to our invasion example, the theological realist would attempt to examine the issue from God's perspective-aside and apart from man's concerns about self-interest, human nature, and the common good. ${ }^{26}$

Thus, the Christian realist abides in all three dimensions-the political, moral, and theological - focusing not on any ultimate victory, but rather on the second-best goal of achieving "limitation and balance." 27 As such, the "Christian realist shares the radical's dissatisfaction with injustice, but focuses on responsible choices among the concrete possibilities now available." ${ }^{28}$ Unlike some secular voices on the left and the right, however, the

23. Perhaps it is in the dimension of moral realism that we most clearly see the themes of hope and humility merge. If theological realism aspires to God's greater glory and political realism is mired in concern over human fallibility, moral realism seems to walk a fine line between optimism and pessimism. Dividing the phrase into its component parts, "moral" strives for the common good, and yet "realism" accepts the vagaries of human nature as a limit on that noble pursuit.

24. Lovin, supra note 13 , at 10.

25. Id. at 11 .

26. This is not to suggest that man's and God's perspectives on the common good can never coincide; indeed, a quick review of King's Civil Rights movement suggests otherwise. Rather, this is to say only that man's perspective is necessarily limited when compared with God's unlimited view, even if man sometimes arrives at the right answer.

27. Lovin, supra note 13 , at 5 .

28. Id. at 5. This shared desire to promote justice and equality make strange bedfellows out of Christian realists and progressive legal scholars in disciplines such as LatCrit Theory and Critical Legal Studies (CLS). See, e.g., Symposium, Class in LatCrit: Theory and Practice in a World of Inequality, 78 DENv. U. L. REv. 467 (2001). CLS cofounder Peter Gabel has asserted his belief that "CLS was always fundamentally a spiritual enterprise that sought to liberate law and legal interpretation from its self-referential, circular, and ideological shackles." Peter Gabel, Critical Legal Studies as a Spiritual Practice, 36 PEPP. L. Rev. 515, 515 (2009). For example, progressive legal scholars have long criticized the racism inherent in immigration policy and politics. See BณL 
Christian realist is not driven to despair when her views are not adopted, trusting that true peace will not be achieved in this life and that, ultimately, it is God's views that should prevail, not hers. As Lovin concludes, "[a] struggle for justice against long odds and substantial opposition may make sense only to those who believe that justice will prevail at the end of history." 29

Mindful of Christ's example and the prophetic tradition, two words might be used to characterize the tension at the core of Christian realism: hope and humility. Both virtues are on display in the thinking of Reinhold Niebuhr, who has been described as a "pessimistic optimist." ${ }^{30}$ As Robert McAfee Brown states:

There is an ultimate optimism in Niebuhr's thought that is often overlooked, especially by his critics: we are recipients of undeserved grace, which means that there are indeterminate possibilities for good on the human scene. . . . But such a sentiment always needs to be qualified to avoid sentimentality, so Niebuhr adopted a provisional pessimism as well. ${ }^{31}$

McAfee Brown sees this embrace of both optimism and pessimismhope and humility-in Niebuhr's statement on democracy: "Man's capacity for justice makes democracy possible; but man's inclination to injustice makes democracy necessary." ${ }^{32}$ Niebuhr saw the U.S. Constitution as the creation of a people who believed in original sin because this founding document imbued each federal branch with tremendous power against the states and the people (optimism/hope), while simultaneously charging each branch with policing the others (pessimism/humility). ${ }^{33}$ This is not an optimistic pessimism, however. Niebuhr was not given to despair, but rather was realistically humble in his assessment of the gains to be achieved in this life, yet was hopeful that mankind would strive to exceed its mortal reach by seeking to do God's will on earth.

So, in embracing theological realism, Christian realists offer hope in espousing the values of a kingdom yet to come. Augustine of Hippo's City of God captured this by extolling the virtue of seeking love on earth as it is

Ong Hing, To Be an American: Cultural Pluralism and the Rhetoric of Assimilation (1997); Robert S. Chang, Center the Immigrant in the Inter/national Imagination, 85 CAL. L. REv. 1395 (1997); Kevin R. Johnson, Race Matters: Immigration Law and Policy Scholarship, Law in the Ivory Tower, and the Legal Indifference of the Race Critique, 2000 U. ILL. L. REv. 525; Ediberto Román, The Alien Invasion?, 45 Hous. L. Rev. 841 (2008).

29. Lovin, supra note 13, at 11.

30. Robert McAfee Brown, The Essential Reinhold Niebuhr, at xi (1986).

31. Id. at $\mathrm{xi}-\mathrm{xii}$.

32. Id. at xii. (quoting Reinhold Niebuhr, The ChIldRen of Light and the ChILdRen of DARKNESS, at ix (1944)). No less a leading light than James Madison expressed a similar sentiment, "But what is government itself, but the greatest of all reflections on human nature? If men were angels, no government would be necessary." THE FEderalist No. 51 (James Madison).

33. BROwN, supra note 30 , at xii. 
in heaven; true peace on earth can be achieved only if human communities reflect God's love and not self-love. ${ }^{34}$ Augustine writes:

[I]t is the conviction of all those who are truly religious, that no one can have true virtue without true piety, that is without the true worship of the true God; and that the virtue which is employed in the service of human glory is not true virtue; still, those who are not citizens of the Eternal City - which the holy Scriptures call the City of God - are of more service to the earthly city when they possess even that sort of virtue than if they are without it. ${ }^{35}$

Similarly, Sóren Kierkegaard lambasted the Danish State Church of his time for its failure to attend to the requirements of the New Testament by focusing more on maintaining political unity between church and state than on the nurturing of individual souls, claiming that, in this form, "Christianity does not exist." ${ }^{36}$ Christ himself distilled the Old Testament law into two commands, neither of which focused on politics or government, but both of which focused on the individual's (not the state's, as Kierkegaard critiqued) duty to love (as Augustine emphasized): "Love the Lord your God with all your heart and with all your soul and with all your mind.' This is the first and greatest commandment. And the second is like it: 'Love your neighbor as yourself.' All the Law and the Prophets hang on these two commandments." ${ }^{37}$ This hope of transcendent, selfless love for God and neighbor fuels the optimism in Christian realism.

Yet, as with Niebuhr's thinking, this hope is tempered with humility borne of the fallenness of man. As the apostle Paul stated in his letter to the Roman church, "for all have sinned and fall short of the glory of God." 38 Just as theological realism aspires for the best in mankind, political realism understands human nature at its worst by vigilantly focusing on self-interest and power. Indeed, both Augustine and Kierkegaard understood the reality of self-interest manifested in the civitas terrena and the Danish State Church, respectively. Similarly, Bonhoeffer decried the Nazis' efforts to force German Christians to adopt their philosophy involving the exclusion of Jews, including converted ones, from the pews. ${ }^{39}$ Aside from being martyred for the cause, Bonhoeffer's witness was so unequivocally clear that it prompted the theologian Karl Barth to confess his own relative lack of concern for the Jews, indicating that Bonhoeffer was "the first and almost the only one to focus so centrally and energetically on the Jewish

34. See generally Augustine of Hippo, Concerning the City of God Agatnst the PaGANs, ch. 19 (Henry Bettenson trans., Penguin Books 2003) (1467).

35. Id. at 213.

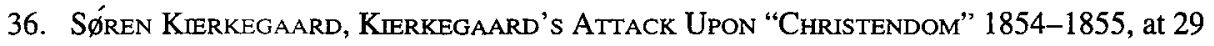
(Walter Lowrie trans., 1946).

37. Matthew 22:37-40 (New International Version).

38. Romans 3:23 (New International Version).

39. J. Deotis Roberts, Bonhoeffer and King: Speaking Truth to Power 89-90 (2005). 
question in 1933." ${ }^{40}$ Man's finitude would suggest that Barth's apparent indifference was likely the more common response to the evil of Nazism than was Bonhoeffer's selfless resistance. Acknowledging one's own sinfulness and self-centeredness helps temper any temptations toward the selfrighteous judging of others and their ideas. Thus, humility refers to the reality of man's fallenness, as well as his recognition of his fallen state.

By incorporating all three dimensions of political, moral, and theological realism, Christian realists like Niebuhr and Augustine embody the twin virtues of hope and humility, recognizing that these values stand in inherent tension, with one end pulling toward the ideal while the other exerts an equal and opposite force toward the real. For President Obama, a political centrist who happens to be a Christian and counts Niebuhr as an influence, Christian realism may well be an attractive vehicle for seeking political common ground while holding firm to one's ideals. Hope tempered by humility challenges one to "work out [one's] salvation with fear and trembling, for [Christians believe] it is God who works in [them] to will and to act according to his good purpose." ${ }^{41}$ Indeed, one might properly characterize Obama's prominent speeches on race (featuring Jeremiah Wright and his grandmother), ${ }^{42}$ abortion (setting a firestorm of protest among many Notre Dame Catholics), ${ }^{43}$ and terrorism (his recent dueling of words with Dick Cheney over torture) as exemplars of a Christian realist politics. ${ }^{44} \mathrm{Can}$ he do this for immigration as well?

It may well be that, unlike during Niebuhr's time when communism and fascism were perceived to be threats to the viability of our democratic institutions, the applicability of Niebuhr's brand of Christian realism to our current host of multilateral, global threats as disparate and amorphous as terrorism and climate change is perhaps less obvious. ${ }^{45}$ Nonetheless, to the extent that U.S. immigration policy continues to operate within a world of sovereign state borders, principles of Christian realism may provide some useful guidance to policymakers, especially those who claim Christianity as their chosen faith, as Obama does.

40. Id. at 90 .

41. Philippians 2:12-13 (New International Version).

42. Barack Obama, U.S. Senator, Press Conference (Mar. 18, 2008) (transcript available at http://www.msnbc.msn.com/id/23690567/).

43. Associated Press, Obama Calls for 'Fair-Minded' Abortion Debate, MSNBC, May 17, 2009, http://www.msnbc.msn.com/id/30782728/.

44. See, e.g., Scott Wilson \& Michael A. Fletcher, In Dueling Speeches, a National Security Debate, WASH. Post, May 22, 2009, available at http://www.washingtonpost.com/wp-dyn/content/article/2009/05/21/AR2009052101748.html?sid=ST2009052101969.

45. That is, while the United States may be concerned about threats to Americans and terrorist attacks on U.S. soil, there does not appear to be the same concern that such threats would replace democracy as the governing ideology. For a collection of essays espousing diverse perspectives on the current relevance of Christian realism, see Christiantry and Power Politics Today: Christian Realism and Contemporary Political Dilemmas (Eric Patterson ed., 2008). 
Parts II and III turn to the twin components of a Christian realist approach to immigration reform, the "hope" and "humility" that must be attended to in seeking a solution that aspires to God's will in the midst of a fallen world.

\section{Messages of Hope: The Biblical Treatment of "Strangers"}

\section{A. Interpreting the Bible and the First Forced Migration: Adam and Eve's Exile from the Garden of Eden}

What better place to begin our study of what Christian realism might have to say about immigration policy than to consult the Bible's treatment of the "alien." First, a caveat: I approach reading the Bible not as an expert, but as a seeker. ${ }^{46}$ While recognizing this is not the only approach, I subscribe to the view that modern skepticism about the Bible's inerrancy does not render it void of divine inspiration. Accordingly, I try to follow biblical scholar James Kugel's advice "to focus first on the text itself, on its very words, and then quite consciously to allow them to speak as best they can about God and man, heaven and earth, and how it is that these may meet."47 Like evangelical author Philip Yancey, I "read the Bible as any ordinary reader does, interacting with the content, trying to understand the author's original intent." 48 In so doing, I worry not about who the author (or authors) might have been, not that such scholarship is unimportant, but that it is secondary to why, as a Christian, I value the Bible for its insights into man's (and my) relationship to God.

Perhaps a brief detour into biblical interpretation will illustrate the difference between my layperson's approach and that which experts employ. Let us take what some consider to be the first example of immigration enforcement alluded to in the Bible: the expulsion of Adam and Eve from the Garden of Eden. ${ }^{49}$ According to Kugel, ancient interpreters and modern biblical scholars differ in their views of the Creation story and the Fall of Man described in the book of Genesis. The story begins with God's creation

46. Cf. Victor C. Romero, An 'Other' Christian Perspective on Lawrence v. Texas, $45 \mathrm{~J}$. CATH. Legal Stud. 115, 115 (2006) (describing how author writes as a "Christian and a teacher of constitutional law," but not an expert in Christian theology). For a thoughtful response to that essay that provides a different Christian reading of Lawrence v. Texas, see John Tuskey, And They Became One Flesh: One Catholic's Response to Victor Romero's "Other" Christian Perspective on Lawrence v. Texas, 35 S.U. L. REv. 631 (2008). Note that, unlike in my Lawrence essay, this piece should not be read as a response to the right; indeed, some might argue that a conservative, enforcement-based immigration policy may be more consistent with Christian realism than the prescriptions I set forth in this essay. As noted in Part V below, I respectfully disagree with this argument, although I acknowledge that I may well be wrong.

47. James L. Kugel, How to Read the Bible 688 (2007).

48. Philip Yancey, The Brble Jesus Read 9 (1999).

49. For example, the United Church of Christ's website lists Adam and Eve's expulsion from the Garden of Eden in Genesis as the first example of a Biblical text on immigration. See United Church of Christ, Biblical References to Immigrants and Refugees, http://www.ucc.org/justice/ immigration/worship/worship-resources/biblical-references-to.html (last visited Apr. 7, 2010). 
of the heavens and earth, followed by the appearance of Adam and Eve, formed by God's own hands, all within a week's time. God gives the couple the Garden of Eden to tend, permitting them to partake of all fruit but that of the Tree of the Knowledge of Good and Evil, on penalty of death. A serpent tempts them to defy God, and they do, leading to their forced migration out of Eden. ${ }^{50}$

Ancient scholarship has bequeathed to contemporary Christians the traditional understanding of the Creation and the Fall: although not literally needing to be viewed as having been accomplished in six days, ${ }^{51}$ the Creation reveals how God is the source of and ruler above all things, including man. Further, God granted the first man and woman an abundant, perfect, and infinite life in the Garden of Eden, but then Adam and Eve, at the Devil's urging, sinned against God, leading to their banishment and subsequent death. Although not part of the Genesis text, the "Fall of Man" has since been used to describe our human condition following Adam and Eve's exile. $^{52}$

In contrast, some modern biblical scholars believe that the Creation story was the product of two authors with two different messages. ${ }^{53}$ The first author, whom speculation suggests was of the priestly class, wrote the initial part of the Creation account, right before Adam and Eve appeared on the scene, not as a message about God's lordship over all, but as a reminder that God completed his work in six days, resting on the seventh. This was essentially a message about keeping the Sabbath! The second author, the one who described the first couple and their fall from grace, was not concerned about the advent of original sin, but rather was attempting to explain a specific point in the development of civilization: ancient man's transition from hunter-gathering to agriculture. In this view, Adam and Eve began their days in an abundant land (Eden) where they could simply hunt and gather to survive, but soon humans learned they had to live off the land directly ("By the sweat of your brow you will eat your food ...."54), and as such, donned more elaborate clothes for protection ("The LORD God made garments of skin for Adam and his wife and clothed them."55). ${ }^{56}$

50. Genesis 1-3 (New International Version).

51. See, e.g., Psalm 90:4 (New International Version) ("For a thousand years in your sight are like a day that has just gone by, or like a watch in the night."). Kugel cites this as an example of how the ancients appreciated God's perspective on time as very different from mankind's. KugEL, supra note 47 , at 49.

52. Id. at 51 (" $[\mathrm{M}]$ ost people think of [the story of Adam and Eve] in these same terms, and they are surprised to learn that the phrase 'Fall of Man' is not to be found in the Genesis story, nor is there any mention of sinless existence in Eden, nor is the serpent identified in the story as the devil (he is just a talking snake).").

53. Indeed, there are others who believe that there are actually two Creation stories in Genesis. See, e.g., James S. Forrester-Brown, The Two Creation Stories in Genesis: A Study of THeIR SyMBolism (1974).

54. Genesis 3:19 (New International Version).

55. Genesis 3:21 (New International Version). 
While my own reading and faith draw me to the ancient rather than the modern interpretation of the Creation and Fall, I agree with Kugel that that interpretive debate should be left to the specialists. ${ }^{57}$ In the section that follows, therefore, we will be sampling biblical texts about alienage and the foreigner, not in an effort to discern who wrote them, but instead to help us better understand how God might view such things. As a Christian, I offer these thoughts with humility, in the spirit of friendly debate and spirited inquiry, ever mindful of my own shortcomings.

\section{B. The Old Testament}

Viewed by many Christians as the story of God's exclusive relationship with the ancient Israelites, the Old Testament or Hebrew Scriptures recognize Jewish "citizenship" as a privileged status: "For you [the people of Israel] are a people holy to the LORD your God. The LORD your God has chosen you out of all the peoples on the face of the earth to be his people, his treasured possession." 58 The scriptures clearly acknowledge the distinction between the Jewish nation and its neighbors, between its God and their gods. ${ }^{59}$ As an example, one need look no further than this curious command from Deuteronomy regarding Jewish food consumption: "Do not eat anything you find already dead. You may give it to an alien living in any of your towns, and he may eat it, or you may sell it to a foreigner. But you are a people holy to the LORD your God." 60 At a definitional level, then, "aliens" or "foreigners" were non-Jews. To be clear, we are not concerned with nations that were enemies of Israel (for often the texts reveal God's deliverance of Israel from or into their hands ${ }^{61}$ ), but Gentiles who did business with and lived among the Jews.

As might be expected, there were likely negative consequences associated with this outsider status, although God would sometimes remind the Israelites that these noncitizens were not to be completely neglected. Often in the text, "aliens" would be grouped together along with other unfortu-

56. Kugel provides more detail on both the ancient and modern interpretations of the Creation and Fall in chapter 2 of How to Read the Bible. Kugel, supra note 47, at 47-57.

57. Id. at 688 ("I certainly have nothing against exploring 'what really happened' and how the Bible came to be written, but I would not mistake such things for what is foremost. They are rightly the province of specialists, people who (like me) got bitten by the bug.").

58. Deuteronomy 7:6 (New International Version).

59. Psalm 81:9 (New International Version) ("You shall have no foreign god among you; you shall not bow down to an alien god.").

60. Deuteronomy 14:21 (New International Version).

61. See, e.g., Deuteronomy 25:19 (New International Version) ("When the LORD your God gives you rest from all the enemies around you in the land he is giving you to possess as an inheritance, you shall blot out the memory of Amalek from under heaven. Do not forget!"); Numbers 25:16-17 (New International Version) ("The LORD said to Moses, 'Treat the Midianites as enemies and kill them ... "”); Lamentations 5:2 (New International Version) ("Our inheritance has been turned over to aliens, our homes to foreigners."). 
nates: "the poor," "the fatherless," and "the widows." were not mentioned among those of the privileged priestly class, the prophets, or kings. Yet, God commanded Israel to "not oppress the widow or the fatherless, the alien or the poor." 63 Certainly less compelling than a positive command to aid these groups, it is striking that the text found it important to set forth this negative right to be free from oppression. Sometimes, God would even require Jews to be somewhat generous, by leaving fallen vineyard grapes ${ }^{64}$ or wheat at a field's edge ${ }^{65}$ for "the poor and the alien." ${ }^{66}$ Further, foreigners were allowed to settle among Israel's tribes, ${ }^{67}$ subject to the same obligations, ${ }^{68}$ and entitled to the same protections, ${ }^{69}$ as the Jews. Solomon and David even conducted a census to count all the noncitizens living in Israel. ${ }^{70}$ This relatively tolerant stance toward the "alien" seems to be borne out of the Jews' own experience as slaves in Egypt: "The alien living with you must be treated as one of your nativeborn. Love him as yourself, for you were aliens in Egypt. I am the LORD your God." 71

In sum, while recognizing status differences between Jews and others (and implicitly acknowledging the ill effects inferior status brings), the Hebrew Scriptures also exhorted the Jews to treat noncitizens in their midst with justice and fairness, if not complete equality: "This is what the LORD

62. See, e.g., Leviticus 23:22 (New International Version) (requiring that gleanings be left for "the poor and the alien"); Psalm 146:9 (New International Version) ("The LORD watches over the alien and sustains the fatherless and the widow ... ").

63. Zechariah 7:10 (New International Version).

64. Leviticus 19:10 (New International Version) ("Do not go over your vineyard a second time or pick up the grapes that have fallen. Leave them for the poor and the alien. I am the LORD your God.").

65. Leviticus 23:22 (New International Version) ("When you reap the harvest of your land, do not reap to the very edges of your field or gather the gleanings of your harvest. Leave them for the poor and the alien. I am the LORD your God.").

66. Accord Deuteronomy 24:20 (New International Version) ("When you beat the olives from your trees, do not go over the branches a second time. Leave what remains for the alien, the fatherless and the widow."). Michael Scaperlanda cites these texts as well in his Catholic Christian critique of the 1996 Welfare Reform Act's harsh effects on immigrants. See Michael A. Scaperlanda, Who Is My Neighbor?: An Essay on Immigrants, Welfare Reform, and the Constitution, 29 ConN. L. Rev. 1587, 1614 (1997).

67. Cf. Ezekiel 47:23 (New International Version) (" "In whatever tribe the alien settles, there you are to give him his inheritance,' declares the Sovereign LORD.").

68. E.g., Numbers 9:14 (New International Version) ("An alien living among you who wants to celebrate the LORD's Passover must do so in accordance with its rules and regulations. You must have the same regulations for the alien and the native born."); Leviticus 20:2 (New International Version) ("Say to the Israelites: 'Any Israelite or any alien living in Israel who gives any of his children to Molech must be put to death ....'”).

69. E.g., Numbers 35:15 (New International Version) ("These six towns will be a place of refuge for Israelites, aliens and any other people living among them, so that anyone who has killed another accidentally can flee there.").

70. 2 Chronicles 2:17 (New International Version) ("Solomon took a census of all the aliens who were in Israel, after the census his father David had taken; and they were found to be $153,600 . ")$.

71. Leviticus 19:34 (New International Version). 
says: Do what is just and right. Rescue from the hand of his oppressor the one who has been robbed. Do no wrong or violence to the alien, the fatherless or the widow, and do not shed innocent blood in this place."72 As with other underclass members of the day-the oppressed, the fatherless, the widowed, the crime victims-"aliens" deserved to be free from harm or violence, and were to be shielded from ill treatment, even if they were not entitled to the same full citizenship that Jews enjoyed.

Of course, for most Christians, the Old Testament is not the final word; these texts must be read in the context of Christ's teachings. To read them too literally or abstractly would obscure their historical significance as words between Israel and its God; these stories told the life and times of a people, the Jews. As we will discover in the next section, Christ provided clues as to how best to interpret these ancient writings in the proper light.

\section{The New Testament}

Chapter Five of Matthew's Gospel opens with the famous Sermon on the Mount, wherein Jesus presents a list of those who, though shunned by mankind, will be welcomed into God's kingdom: the poor in spirit, the meek, those in mourning, those who hunger for righteousness, the merciful, and so on.$^{73}$ Perhaps concerned that his list might be misunderstood, Jesus reminds the crowd of the enduring significance of the ancient scriptures as outlined in the Mosaic law and the words of the Hebrew prophets: "Do not think that I have come to abolish the Law or the Prophets; I have not come to abolish them but to fulfill them."74 Jesus then gives examples of what he expects-one violates the commandment against murder by simply being angry with another; looking lustfully at another woman renders a man guilty of adultery in his heart; one must love and pray for one's enemies, not just one's friends. ${ }^{75}$

In short, Jesus asks us to go beyond the letter of the law to understand its spirit. We are required not only not to murder, but to avoid wishing evil on another; we are asked not only to not sleep with another's wife, but to avoid even entertaining such a thought; we are asked to pray for our enemies just as we would our friends. Jesus later summarizes his gloss on Mosaic law in response to the question:

"Teacher, which is the greatest commandment in the Law?" Jesus replied: "Love the Lord your God with all your heart and with all your soul and with all your mind.' This is the first and greatest commandment. And the second is like it: 'Love your neighbor as

72. Jeremiah 22:3 (New International Version).

73. Matthew 5:1-10 (New International Version).

74. Matthew 5:17 (New International Version).

75. Matthew 5:21-22 (New International Version) (murder); Matthew 5:27-28 (New International Version) (adultery); Matthew 5:43-48 (New International Version) (love for enemies). 
yourself.' All the Law and the Prophets hang on these two commandments." 76

Understood in context, then, Jesus's reading of the Hebrew Scriptures means that we need to go beyond the minimum required by the law and seek to fulfill and embody the spirit of peace and generosity that we imagine God to desire, and we do this in the service of our neighbor. This is no plea for maudlin sentimentality; this is a difficult demand for our extension of genuine, sacrificial care to others.

Jesus himself did not set forth a standard he was unwilling to meet. Christians believe that it was Jesus's death on the cross and his resurrection that bridged the divide between man and God created by Adam and Eve's original sin. 77 This is the gospel or "good news" that Christians preach. As the apostle Paul wrote to the Roman church: "[T]hrough Christ Jesus the law of the Spirit of life set me free from the law of sin and death."78 Many Christians believe that the proper response to Jesus's sacrifice is for us, in turn, to lead joyful lives in the spirit of sacrifice, and not to be content to simply follow the letter of the law. Reading the Old Testament texts on alienage in this light might mean a Christian obligation to do more than just avoiding harm to noncitizens (although that would be the least the spirit requires), or more than simply leaving the leftovers of the field or the vineyard to them, like scraps for scavenging dogs.

A critic might respond that the command to love one's neighbor surely does not include the foreigner. Indeed, in a well-known passage from Luke's gospel, a lawyer familiar with Jesus's summary of the Mosaic law sought further clarification:

On one occasion an expert in the law stood up to test Jesus.

"Teacher," he asked, "what must I do to inherit eternal life?" it?"

"What is written in the Law?" he replied. "How do you read

He answered: "'Love the Lord your God with all your heart and with all your soul and with all your strength and with all your mind'; and, 'Love your neighbor as yourself.',"

"You have answered correctly," Jesus replied. "Do this and you will live."

But he wanted to justify himself, so he asked Jesus, "And who is my neighbor?"79

76. Matthew 22:36-40 (New International Version).

77. Not being an expert in these matters, I do not mean to oversimplify things: the Christian doctrine of atonement, like many philosophical puzzles, is exceedingly complex. See, e.g., PETER Schmiechen, Saving Power: Theories of Atonement and Forms of the Church (2005) (presenting an analysis of ten theories of Christian atonement).

78. Romans 8:2 (New International Version).

79. Luke 10:25-29 (New International Version); see also Scaperlanda, supra note 66, at 1612-13 ("The Parable of the Good Samaritan provides an excellent backdrop to illustrate my Catholic Christian vision of America's constitutional duty toward permanent resident aliens."). 
Jesus then proceeded to tell the famous Parable of the Good Samaritan, in which a Jew, traveling from Jerusalem to Jericho, was beaten by robbers and left for dead by the side of the highway. Two other Jews-a priest and a Levite, typically assistants to the priests ${ }^{80}$ - came upon the man at different times, but ignored him and walked past. After some time, a Samaritan, an ethnic minority "scorned by the Jews because of their mixed Jewish and Gentile ancestry," 81 came upon the man, took pity on him, and took care of him, not only by dressing his wounds, but also by taking him to an inn and paying for his stay there until he had fully recovered. ${ }^{82}$

After telling this story, Jesus turned to the lawyer and asked him which person acted as a neighbor to the injured man; indicating the Samaritan, the lawyer replied, "The one who had mercy on him." 83 Jesus then said simply, "Go and do likewise." 84

By highlighting that it was a despised minority, and not the pious brethren, that came to the man's aid, Jesus calls the lawyer to render compassionate service even to those whom society despises. This should come as no surprise, given Jesus's earlier reading of the Mosaic law requiring that Christians love and pray for our enemies, not just our friends. Jesus therefore calls mankind out of its "realist" tendencies-out of its self-interested, status-quo-oriented comfort zone by challenging all to extend "mercy" to those whom society normally thinks of as the least.

What does "rendering mercy" look like apart from the specific instance spelled out in the parable? At one level, leaving unharvested wheat or grapes for those less well-off is a form of mercy (as well as an Old Testament command). One answer to this question appears toward the end of Matthew's Gospel. In his Parable of the Sheep and the Goats, ${ }^{85}$ Jesus gives a glimpse of Judgment Day, when God will hold all accountable for their lives on earth, to assess whether they have remained faithful to the two great commands to love God and neighbor. In what some consider one of the most challenging texts for Christians, Jesus describes a scene where, sitting on his throne at the end of time, the King divides mankind into two groups, as a shepherd would the sheep from the goats.

To those whom he welcomes into heaven, the King is generous with praise:

For I was hungry and you gave me something to eat, I was thirsty and you gave me something to drink, I was a stranger and you invited me in, I needed clothes and you clothed me, I was sick

80. See John F. Walvoord, Roy B. Zuk \& Louis A. Barbieri, Bible Knowledge ComMENTARY: New TESTAMENT 234 (1983) ("Levites were descendants of Levi, but not of Aaron, and they assisted the priests (Aaron's descendants) in the temple.").

81. Id. at 234 .

82. Luke 10:30-35 (New International Version).

83. Luke 10:37 (New International Version).

84. Id..

85. Matthew 25:31-46 (New International Version). 
and you looked after me, I was in prison and you came to visit me. ${ }^{86}$

When the righteous object in bewilderment that they never served the King during their lifetimes, he replies, "I tell you the truth, whatever you did for one of the least of these brothers of mine, you did for me." 87

To those whom he rejects, the King is quick to rebuke, faulting them for not caring for their most burdened brethren. The damned also object, to which the King provides a parallel response, "I tell you the truth, whatever you did not do for one of the least of these, you did not do for me." 88

This parable provides examples of the kind of mercy Jesus expects Christians to render: service to society's most vulnerable-the hungry, the thirsty, the stranger, the naked, the sick, and the prisoner. While even the well-off are occasionally hungry and thirsty (especially in tough economic times), this passage appears to focus most specifically on the perpetually poor and oppressed, which explains why neither the "sheep" nor the "goats" could see the face of God in them. After all, it is human nature to see beauty in what society considers beautiful, not in what it ignores.

What we learn, then, from Jesus's teachings is that Christians are called to fulfill the Mosaic law_-loving God and neighbor-by attending to its spirit: not just by avoiding sin out of self-interest, but by joyfully meeting the needs of the worst-off in society, ${ }^{89}$ or as the Letter to the Hebrews puts it, "Do not neglect to show hospitality to strangers, for by this some have entertained angels without knowing it."90 Theology professor Paul Lim notes that, in this verse, the original Greek word for "hospitality""philoxenia" - means "the love of strangers" or the opposite of xenophobia $^{91}$; such an interpretation is certainly consistent with our reading of Jesus's teachings.

As might be expected, applying this lesson of hope to the treatment of noncitizens, while uplifting, yields precious little in terms of concrete policy recommendations. From a Christian realist perspective, though, I believe this exercise provides a distinct, though somewhat opaque, lens through which to view our options: Christians are called to do more than

86. Matthew 25:35-36 (New International Version).

87. Matthew 25:40 (New International Version).

88. Matthew 25:41-45 (New International Version).

89. Some describe this particular philosophy as the Social Gospel movement, so-called because of its emphasis on progressive, social, and political action in favor of the poor and downtrodden as a means of living out Jesus's commands. See, e.g., Walter Rauschenbusch, A Theology for the Social Gospel (1922); Charles Howard Hopkins, The Rise of the SoCIAl Gospel in American Protestantism, 1865-1915 (5th prtg. 1957). While embracing the commitment to serving the unfortunates of the world, Christian realism differs from the Social Gospel movement in that it is skeptical that any man-made solution to prevailing social ills can succeed, given man's inherent sinfulness. See supra Part I.

90. Hebrews 13:2 (New American Standard Bible Version).

91. David Van Biema, Does the Bible Support Sanctuary?, Time, July 20, 2007, http://www. time.com/time/world/article/0,8599,1645646,00.html. 
what God asked of the Israelites, to do more than tolerate and occasionally support the Gentiles in their midst. Jesus the shepherd calls Christians to be his "sheep," which includes an obligation to welcome the stranger. ${ }^{92}$ Even when pressed against the reality of self-interest and power politics, a truly Christian realist perspective advocating executive leadership in immigration reform should take that mandate seriously as part of God's hope for mankind. Because "now we see through a glass, darkly," 93 our limited vision often obscures the horizon, but that should not dissuade Christian realists from prayerfully seeking to discern what that view should look like.

\section{Lessons in HumiLity: ReAlism ANd ENForCEMENT}

Jesus Christ's vision of heaven has sometimes been referred to as the "Upside-Down Kingdom"94 because his way is not man's way: the world promises riches to the strong and proud, while Jesus promises God's kingdom to the meek and the poor in spirit. ${ }^{95}$ The "realism" in Christian realism acknowledges the world's way without accepting it, seeking to find ways to accomplish God's alternate vision within the parameters of a selfish world.

As has been true from the time of the Old Testament, peoples organize themselves in nation-states and those who are not citizens of a state are not afforded the same status as those who are, even in liberal democracies. ${ }^{96}$ As such, two "rule of law" realities arise that affect any policy discussion on immigration in the United States: the first is the superior status that U.S. citizenship bestows upon some and correspondingly denies others. ${ }^{97}$ While noncitizens who permanently and lawfully reside here enjoy many benefits, they have limited rights to others. Furthermore, most U.S. citizens accept that status differentiation as a significant one worth preserving. While not an insurmountable problem, it is a starting point that must be attended to. A second, and related, reality to the U.S. citizen/noncitizen divide is the lawful resident/undocumented immigrant distinction. Our lawmakers accept

92. Matthew 25:35 (New International Version) ("I was a stranger and you invited me in $. ")$.

93. 1 Corinthians 13:12 (King James Version).

94. See, e.g., Donald B. Kraybill, The Upside-Down Kingdom (1978).

95. Matthew 5:3 (New International Version) (poor in spirit); Matthew 5:5 (New International Version) (meek).

96. Both Bruce Ackerman and Michael Walzer have acknowledged this citizen-noncitizen divide. See, e.g., Bruce A. Ackerman, Social Justice in the Liberal State 71 (1980) ("For I hope to convince you that the constitution of a liberal democracy should guarantee the basic rights of citizens even when they are threatened by a hostile majority. In contrast, the fate of noncitizens will be an appropriate subject for majoritarian politics. It follows that the dialogic rights of citizens are grounds of a far firmer foundation than those that any noncitizen may possess."); Mrchael Walzer, Spheres of Justice 62 (1983) ("For these [citizenship] rights are to be exercised only by the community as a whole (even if, in practice, some national majority dominates the decision making) and only with regard to foreigners, not by some members with regard to others.").

97. See generally Linda Bosniak, The Crtizen and the Alien (2006). 
that most of their constituents see the line between those lawfully here and those who are not as a bright line that should not be crossed blithely.

Together, these two realities produce a third, more subtle effect: because the law draws, and the citizenry accepts, distinctions between citizens and noncitizens, and between those lawfully present and those who are not, there is a tendency to neglect-or worse, actively oppress-those in the disfavored group for no better reason than that the law allows it. Indeed, U.S. history is replete with examples of how its immigration laws, rather than upholding Lady Liberty's promise of welcoming the world's unwanted, have served instead as a barrier to racial, ideological, gender, and sexual minorities. ${ }^{98}$

Discriminatory laws aside, at the very least, an influx of immigrants provokes curiosity among the natives, as well as the newcomers, as each learns how to get along with the other. As social ethicist Lovin explains:

When new immigrants flow into a community, the old residents and the new alike become amateur anthropologists, trying to understand the world as others see it in relation to the world of their own experience. As economic pressures, mobility, and expanded choices create new lifestyles, family patterns, and work roles, people have to make new choices, not only about how they will live, but how they will live with the choices their neighbors make. ${ }^{99}$

Of course, in reality, it is the natives, the citizens who get to define the rules for the community, and it is up to the newcomers to adjust.

These three realities - the privilege of citizenship, the curse of illegal status, and the tendency by the strong to neglect/oppress the weak-find expression in current policies and practices toward immigration and immigrants, both at the federal and state levels. To be fair, President Obama has taken concrete steps to correct several policies and procedures he inherited from the Bush Administration in an effort to restore some semblance of due process in immigration proceedings, including administratively suspending the so-called widow's penalty ${ }^{100}$ and restoring the right of deportees to lodge complaints of ineffective assistance of counsel. ${ }^{101}$ However, as a cen-

98. See generally Bull Ong Hing, Deporting Our Souls: Values, Moraltty, and Immigration Policy (2006); Kevin R. Johnson, The "Huddled Masses Myth": Immigration and Civil Rights (2004); Victor C. Romero, Alienated: Immigrant Rights, the Constitution, AND EQUALITY IN AMERICA (2005).

99. Lovin, supra note 13, at 84-85.

100. Press Release, U.S. Dep't of Homeland Sec., DHS Establishes Interim Relief for Widows of U.S. Citizens (June 9, 2009), available at http://www.dhs.gov/ynews/releases/pr_1244578412 $501 . \mathrm{shtm}$. As of this writing, Congress is working to pass legislation to eliminate the penalty; President Obama is expected to sign the proposed bill. See, e.g., Kirk Semple, Measure Gives Rights to Widows of Citizens, N.Y. Times, Oct. 21, 2009, at A19.

101. Matter of Compean, 25 I. \& N. Dec. 1 (A.G. 2009) (vacating prior decision, thereby restoring BIA and IJ authority to review motions to reopen based on claims of ineffective assistance of counsel). In a related case this term, the Supreme Court is considering whether a longtime 
trist and a realist, he and other executive officials at the federal and state levels have had to face several constraints that embody the realities identified above.

First, having robust interior and border enforcement policies at the federal level appears to be nonnegotiable. No less a liberal rag than the New York Times has declared, "Make no mistake: Stronger and more effective immigration enforcement should be a pillar of any reform plan." ${ }^{102}$ Regardless if one agrees with the current criteria for admission, it is reasonable to expect that a nation will act to secure its borders, facilitating the entry of only those with proper documents and deporting others who have failed to abide by the terms of their stay here. Indeed, one might think about the government's enforcement of immigration laws as not unlike how parties to a contract seek to enforce its terms: compliant parties receive the benefit of their bargain; deal breakers do not. ${ }^{103}$ This follows a long-standing perception $^{104}$ that the federal government has, until recently, been lax on enforcement; the Bush Administration quickly remedied that with a string of highprofile raids on communities and companies thought to employ undocumented immigrants, with the Postville, Iowa raid being the most recent prominent case. ${ }^{105}$ Tough workplace enforcement has highly foreseeable, if

permanent resident has been deprived his Sixth Amendment right to effective of assistance counsel when he faces deportation in reliance on erroneous advice from his attorney that pleading guilty to felony drug trafficking would not have adverse immigration consequences. See Padilla $v$. Kentucky, 253 S.W.3d 482 (Ky. 2008), cert. granted, 129 S. Ct. 1317 (U.S. Feb. 23, 2009) (No. 08-651).

102. Editorial, Hope and Worry on Immigration, N.Y. TIMES, June 5, 2009, at A22.

103. Hiroshi Motomura describes this view as "immigration as contract." HrRoshI Motomura, Americans in Warting: The Lost Story of Immigration and Citizenship in the UnTted States 15 (2006) (citing Chinese Exclusion Case as example of this); see also Victor C. Romero, U.S. Immigration Policy: Contract or Human Rights Law?, 32 Nova L. Rev. 309 (2008) (describing U.S. immigration policy to be more like contract law in operation than a guarantee of human rights).

104. The truth of the U.S. government's enforcement of immigration laws is, of course, more nuanced than this perception suggests. As historian Mae Ngai's research suggests, the stereotypical Latino "illegal alien" is a relatively recent phenomenon in American history because for many years, the U.S.-Mexico border was essentially porous, so as to facilitate the free travel of Mexican labor to work the fields and factories of the southern United States border states. See MAE M. Ngai, Impossible Subjects: Illegal Aliens and the Making of Modern AMerica 64 (2004) ("Immigration inspectors ignored Mexicans coming into the southwestern United States during the 1900 s and 1920s to work in railroad construction, mining, and agriculture. The Immigration Bureau did not seriously consider Mexican immigration within its purview, but rather as something that was 'regulated by labor market demands in [the southwestern] border states.' The bureau also described the Southwest as the 'natural habitat' of Mexicans, acknowledging, albeit strangely, Mexicans' claims of belonging in an area that had once been part of Mexico. The Immigration Act of 1917 doubled the head tax and imposed a literacy test, erecting the first barriers to entry, but unlawful entry was limited, as the Labor Department exempted Mexicans from the requirements during the war. It was not until 1919 that Mexicans entering the United States were required to apply for admission at lawfully designated ports of entry.").

105. The DePaul Journal for Social Justice ran a special symposium issue on the Postville raids. See Rose Rivera, Letter to Our Readers: Introduction to the Postville Raids Symposium, 2 DePaul J. Soc. Just. at i, i-ii (2008); see also Shoba Sivaprasad Wadhia, Under Arrest: Immi- 
not always intentional, consequences such as the separation of alleged undocumented parent workers from their U.S. citizen children ${ }^{106}$ and the invasion of individuals' privacy rights. ${ }^{107}$ Large enforcement actions involving many agencies and their officers, immigrants and their families, will inevitably lead to occasional mistakes borne out of the desire to proceed expeditiously; as with many human endeavors, accuracy is sacrificed when efficiency is sought. For instance, during the infamous Operation Wetback of the 1950s, many U.S. citizens were mistakenly deported along with the approximately two million Mexicans targeted by that initiative. ${ }^{108}$ The challenge will be to meet this desire to abide by the rule of law balanced against the requirement that individuals be treated with due process.

Second, states and localities demand to be involved in immigration regulation. The National Conference of State Legislatures recently reported that since 2005, when 300 bills and 38 state laws were passed regarding immigration issues, 2006 saw that activity double ( 570 bills introduced and 84 laws passed), and 2007 saw it triple from the prior year (1,562 bills introduced and 240 laws passed). ${ }^{109}$ Scholarly analysis has grown commensurately. ${ }^{110}$ Many commentators believe that because states and local gov-

grants' Rights and the Rule of Law, 38 U. MEM. L. REV. 853, 863-64 (2008) (describing the raids that followed the collapse of negotiations over federal immigration reform in 2006 and 2007).

106. See, e.g., David B. Thronson, Creating Crisis: Immigration Raids and the Destabilization of Immigrant Families, 43 WAKE ForeST L. REv. 391, 397-98 (2008) (describing mixed-immigration status families, characterizing those involving a U.S.-born citizen child and immigrant parent as "common").

107. See generally Raquel Aldana, Of Katz and "Aliens": Privacy Expectations and the Immigration Raids, 41 U.C. DAvIS L. REv. 1081 (2008) (examining noncitizens' privacy expectations in the context of immigration raids).

108. See, e.g., David E. Lorey, The U.S.-Mexican Border IN the Twentieth Century 121 (1999) ("The infamous Operation Wetback of 1953-1955 deported two million Mexicans (and many U.S. citizens of Mexican heritage) to the region across the boundary.").

109. Legislative activity for 2008 and 2009 has remained at about the same high level as in 2007. Nat'l Conference of State Legislatures, 2009 Immigration-Related Bills and ResOLUTIONS IN THE STATES (JANUARY-MARCH 2009) (2009), available at http://www.ncsl.org/print/ immig/2009ImmigFinalApril222009.pdf.

110. As early as 2002 , legal scholars could see the growing desire of state and local governments to be involved in immigration enforcement looming on the horizon; indeed, NYU held a symposium at its law school to address issues relating to state and local control of immigration authority. See Michael J. Wishnie, Introduction: Immigration and Federalism, 58 N.Y.U. ANN. Surv. Am. L. 283, 286 (2002). Since then, the writing in this area has blossomed manifold. See, e.g., Keith Aoki, (In)visible Cities: Three Local Government Models and Immigration Regulation, 10 OR. Rev. Int'L L. 453 (2008); Nathan G. Cortez, The Local Dilemma: Preemption and the Role of Federal Standards in State and Local Immigration Laws, 61 SMU L. REV. 47 (2008); Clare Huntington, The Constitutional Dimension of Immigration Federalism, 61 VAND. L. Rev. 787 (2008); Huyen Pham, The Constitutional Right Not to Cooperate?: Local Sovereignty and the Federal Immigration Power, 74 U. CrN. L. Rev. 1373 (2006); Huyen Pham, The Inherent Flaws in the Inherent Authority Position: Why Inviting Local Enforcement of Immigration Law Violates the Constitution, 31 FlA. ST. U. L. Rev. 965 (2004); Michael A. Olivas, Immigration-Related State and Local Ordinances: Preemption, Prejudice, and the Proper Role for Enforcement, 2007 U. ChI. Legal F. 27 (2007); Juliet P. Stumpf, States of Confusion: The Rise of State and Local Power over Immigration, 86 N.C. L. Rev. 1557 (2008); Rick Su, A Localist Reading of Local 
ernments feel they bear the direct impact of (especially undocumented) immigration and because the federal government has not always been especially rigorous in its enforcement, states and localities have decided to take matters into their own hands by passing a range of laws, from those assisting immigrant assimilation to those that discourage undocumented settlement. Effective federal leadership must find ways to harness the energy and frustration coming out of the states in positive and productive ways.

Third, not unimportantly, because of the emphasis on enforcement and the growing role of states and localities therein, the rhetorical war has been lost. Terms designed to convey mercy, forgiveness, and reconciliation to the undocumented-like "amnesty" and "sanctuary" (and for that matter, "empathy"111)_seem to be political nonstarters in today's highly politicized climate.

"Amnesty" refers to the ability of long-time undocumented migrants to adjust to a legal immigration status; though experts and lawmakers know this, many in the public forget that it was Republican President Ronald Reagan who signed the last "amnesty" bill in $1986 .{ }^{112}$ Instead, opponents today appear to view such a program as an unconditional pardon, a clear violation of the rule of law. Looking both at the 1986 bill and at proposals proffered by both Obama, and his predecessor, Bush, none were ever unconditional; rather, successful adjustees must pay a fine and comply with several strict requirements. Given "amnesty's" currently tainted meaning, however, proponents have chosen a "path to legalization"113 as the preferred phrase.

"Sanctuary" has likewise experienced a fall from grace. Originally used to describe the physical, spiritual, and advocacy support religious organizations gave thousands of Central American refugees during the 1980s, "sanctuary" has since been used pejoratively to describe cities that "shield" or "harbor" undocumented persons from federal authorities. Professor Rose Cuison Villazor has even argued that the social and political costs associ-

Immigration Regulations, 86 N.C. L. REv. 1619 (2008); Michael J. Wishnie, State and Local Police Enforcement of Immigration Laws, 6 U. PA. J. Const. L. 1084 (2004). While most commentary has been critical or cautious of state and local involvement in immigration matters, some have welcomed these developments. See, e.g., Kris W. Kobach, The Quintessential Force Multiplier: The Inherent Authority of Local Police to Make Immigration Arrests, 69 ALB. L. Rev. 179 (2006).

111. Witness the brouhaha over Sonia Sotomayor's nomination to the Supreme Court when President Obama called for the appointment of judges with "empathy": "Republicans have signaled that they intend to put the eventual nominee under a microscope, and they say they were put on guard by Mr. Obama's statement that judges should have 'empathy,' a word they suggest could be code for injecting liberal ideology in the law." Charlie Savage, A Judge's View of Judging, N.Y. Times, May 15, 2009, at A21.

112. See Edwin Meese III, Op-Ed., An Amnesty by Any Other Name ..., N.Y. Times, May 24, 2006, http://www.nytimes.com/2006/05/24/opinion/24meese.html (describing his views of the 2006 amnesty bill compared with the 1986 one).

113. See, e.g., NPR News \& Notes, Reid Backs 'Path to Legalization' for Immigrants, NATIONAL Public Radio, March 28, 2006, http://www.npr.org/templates/story/story.php?storyId=53 05432. 
ated with the term "sanctuary" suggest that it may well be time to seek new language to further the cause of immigrant rights. ${ }^{114}$

The rule of law and its tendency toward enforcement at the federal, state, and local levels, the foreseeable harms that come with zealous execution, and the negative rhetoric that ensues create a reality that high-level executives like President Obama will have to contend with in balancing "hope" and "humility." Without an eye on the existing political climate and man's inevitable slide toward self-interested behavior, any attempts to appeal to "hope" as exemplified in the Gospel's mandates would likely be futile. The next section hopes to bring together what we have learned about Christian realism, scripture, and U.S. immigration policy's promises and pitfalls into much sharper focus, in an attempt to suggest possible opportunities for executive leadership.

IV. A Christian Realist Alternative: PRIORITIZING INTEGRATION OVER ENFORCEMENT

In December 2005, the House of Representatives passed what was regarded as one of the most restrictive immigration bills to date, The Border Protection, Antiterrorism, and Illegal Immigration Reform Act of 2005. ${ }^{15}$ Catholic Cardinal Roger Mahony of Los Angeles denounced the bill's proposal that elevated to a felony the crime of aiding and abetting undocumented persons. Aside from indicating that he would instruct priests to defy any law requiring that they demand to see proof of lawful status before serving immigrants in need, Mahony said:

The whole concept of punishing people who serve immigrants is un-American. If you take this to its logical, ludicrous extreme, every single person who comes up to receive Holy Communion, you have to ask them to show papers. It becomes absurd and the [C] ]hurch is not about to get into that. ${ }^{116}$

Outrage in the Latino community and elsewhere was similarly heartfelt, and the bill never became law.

Cardinal Mahony's witness and leadership in the face of a potentially excessive and unwise enforcement regime provides an example for a viable Christian realist approach to immigration reform in two concrete ways. First, Mahony was direct, forceful and unstinting in his advocacy that extreme enforcement would be both illogical and immoral. Second, through his remarks, he, perhaps unwittingly, promoted assistance and hospitality to

114. Rose Cuison Villazor, What is a "Sanctuary?," 61 SMU L. Rev. 133, 133 (2008) ("given the social and political costs associated with the term sanctuary, it may well be time to reconsider its rhetorical utility in creating safe havens for immigrants.").

115. H.R. 4437, 109th Cong. (1st Sess. 2005).

116. Leo Chavez, The Latino Threat: Constructing Immigrants, Citizens, and the NaTION 154 (2008) (citing Teresa Watanabe, Immigrants Gain Pulpit, L.A. Times, March 1, 2006, at A1). 
the immigrant as an alternate policy to the enforcement regime promoted by the House. In these two strategies-clear and forceful rhetoric, on the one hand, and integration rather than enforcement, on the other-we have a blueprint for effective executive leadership on immigration reform.

\section{A. Clear and Forceful Rhetoric to Help Change the Terms of the Discourse}

Opponents and proponents alike are quick to point out President Obama's gift for speech. His addresses and stated positions on such controversial issues as race relations, abortion, and terrorism reveal a thoughtful, subtly nuanced mind at work, unafraid to say what he believes even on the most difficult of subjects. Despite his willingness to stake a claim, Obama does not, however, seek to demonize his opponents. Hence, while not a few who listened to his speech on abortion at Notre Dame's commencement were angered by his position (and indeed some, by his very presence there, given that position), Obama's words were ones of reconciliation and mutual respect, asking those on both sides of the debate to stop "reducing those with differing views to caricature. Open hearts. Open minds. Fair-minded words. It's a way of life that always has been the Notre Dame tradition."117

Just as he has done in the past, Obama has the opportunity to exercise his gifts of speaking and leadership by promoting a change in the rhetoric surrounding immigration and immigrant rights. Specifically, he could start by reclaiming the words "amnesty" and "sanctuary." Like "hospitality," both terms have spiritual meanings that suggest bridging the divide between the privileged and the oppressed, between the lawmaker and the lawbreaker. The terms suggest reconciliation and a desire to move forward, both of which are necessary components of advancing a politics that seeks to assimilate and welcome newcomers rather than to exclude them unnecessarily. Like Cardinal Mahony, Obama's decision to deploy such words would signal a witness to service of the underprivileged and a reaffirmation of America as a nation of immigrants. By embracing the rhetoric of integration and acceptance embodied in "amnesty" and "sanctuary," Obama would come closer to approximating Mahony's prophetic call.

Indeed, "amnesty" and "sanctuary" are, arguably, perfect Christian realist terms to embrace in the debate over immigration. While they convey the hope of assimilation, redemption, and relief, they also simultaneously acknowledge the limitation, the sinfulness, and the shortcomings of being human. "Amnesty" and "sanctuary" promise forgiveness and reconciliation by bridging the gap between those who make the laws and those who have failed to abide by them, between the insider and the outsider.

However, rhetorical change is not enough. The next two sections will outline opportunities to highlight actual concrete reforms that have em-

117. Associated Press, supra note 43. 
braced the integration of immigrants, even in this climate of stepped-up enforcement.

\section{B. States and Local Governments Should Favor Integration over Enforcement}

President Obama's administration should actively encourage all efforts by cities and states to assist the assimilation and integration of immigrants into their communities. ${ }^{18}$ The nonprofit Migration Policy Institute, for example, awards its four annual $E$ Pluribus Unum prizes of $\$ 50,000$ each to programs, public or private, that effectively promote immigrant assimilation. ${ }^{119}$ While perhaps a cash prize would appear unseemly in this era of the government bailout, the federal government approving immigrant assimilation reaffirms the nation's history as an immigrant destination.

Second, the federal government should immediately end or suspend its 287(g) agreements allowing state and local governments to help enforce immigration law in light of the Government Accountability Office's (GAO) January 2009 report that the program is in need of "better controls." 120 Though these agreements have been lauded by some for their leveraging of state and local governments' desire to boost federal immigration enforcement capabilities, the GAO found that federal officials have failed to provide clear objectives and effective training of their state and local partners. The Washington Post noted that some community activists believe such agreements have led to racial profiling of Latinos or pretextual stops for minor violations in order to check one's immigration status. ${ }^{121}$

In contrast, a few cities have taken the opposite approach, rejecting such agreements in favor of creating welcoming communities for undocumented persons. Following San Francisco's lead, Oakland recently decided to issue identification cards to undocumented immigrants as a means to obtain city services. City officials also hope the cards will spur good citi-

118. As Cristina Rodriguez suggests, "We might allow states and cities to compete for immigrants, or the federal government might give states incentives to attract immigrants and treat them as quasi citizens. This cooperative federal-state-local process might ultimately produce the sorts of institutional grounding that social stability requires. Such an approach is not a perfect substitute for national citizenship because only national citizenship can confer on immigrants the right to remain. But it might be a mechanism for negotiating the different migration dynamics currently working at cross-purposes." Cristina Rodriguez, The Citizenship Paradox in a Transnational Age, 106 Mich. L. REv. 1111, 1128 (2008).

119. See E Pluribus Unum Prizes, http://www.migrationinformation.org/integrationawards/ (last visited Apr. 9, 2010). More recently, the Spring Institute for Intercultural Learning and the Illinois Coalition for Immigrant and Refugee Rights hosted a National Immigrant Integration Conference from June 24-26, 2009. See Nat'1 Immigrant Integration Conference, http://www.integrationconference.org/?action=agenda (last visited Apr. 9, 2010).

120. U.S. Government ACCOUntabitity Office, Immigration Enforcement: Better Controls Needed over Program Authorizing State and Local Enforcement of Federal IMMIGRATION LAws (2009), available at http://www.gao.gov/new.items/d09109.pdf.

121. N.C. Aizenman, Report Cites Problems in ICE Training Program: GAO Says Key Controls Are Missing, WAsh. Post, Mar. 4, 2009, at A02. 
zenship and enhance cooperation with local law enforcement. ${ }^{122}$ State and local executives and lawmakers have much to gain by studying these cities' experiences alongside those of the more infamous restrictionist localities like Hazleton, Pennsylvania. ${ }^{123}$

In sum, federal, state, and local leaders should promote integration and assimilation of immigrants while halting all efforts to create cooperative enforcement regimes that fail to adequately secure immigrant rights. Such an approach also happens to promote the biblical directive to welcome the stranger, while taking into account the political realities that drive the desire for enforcement and state/local participation in immigration policy.

\section{National Government: Toward Comprehensive Immigration Reform}

As mentioned earlier, President Obama's administration has begun to correct some of the more egregious mistakes made by his predecessor, but there is still much work to be done. Aside from utilizing to good effect his rhetorical skills in helping to define a civilized debate on the issue, President Obama should have a two-tier strategy toward immigration reform: First, he should-as he has with the economic recovery plan, health care reform, and climate change-seek a bold, comprehensive solution to our immigration woes that secures permanent amnesty for the 12 million undocumented ${ }^{124}$ so that they may adjust their status after penalty, and thereafter commit sufficient resources for effective and humane enforcement as well as efficient service to those immigrants whose paperwork is already in the queue. Indeed, a recent Council on Foreign Relations task report on immigration reform favors a comprehensive overhauling of our beleaguered system. ${ }^{125}$

122. Anna Gorman, Oakland to Offer Identification Cards for Illegal Immigrants, L.A. TIMEs, June 5, 2009, http://www.latimes.com/news/local/la-me-idcard5-2009jun05,0,1333636.story. Similarly, New Haven also has a municipal I.D. card program. See City of New Haven, http://www. cityofnewhaven.com/Government/NewHavenResidents.asp (last visited Apr. 9, 2010) (describing requirements for Elm City Resident Card).

123. On a smaller scale, but on a no less important issue, there have been reports of undocumented immigrants being denied marriage licenses for failure to produce a Social Security Number. Fortunately, advocates have mobilized to inform civil servants on how persons without federal Social Security numbers, such as the undocumented, are not required to produce them to obtain a state marriage license. See Memo from Bishop Soto to All (Arch)Bishops, Regarding Denial of Marriage Licenses for Undocumented Immigrants, Apr. 3, 2009 (on file with author); see also Maria Pabón López, A Tale of Two Systems: Analyzing the Treatment of Noncitizen Families: In State Family Law Systems and Under the Immigration Law System, 11 HARv. LATINO L. REv. 229, 232 (2008) (discussing denial of state marriage licenses).

124. For an enlightening Hartian dialectic exploring both sides of the immigration debate, see Stephen H. Legomsky, Portraits of the Undocumented Immigrant, 44 GA. L. Rev. 65 (2009).

125. Councl on Foreign Relations, U.S. Immigration Policy: Independent Task Force RePort No. 63, (2009); Spencer Hsu, Obama Revives Bush Idea to Catch Illegal Workers, WASH. Post, July 9, 2009, available at http://www.washingtonpost.com/wp-dyn/content/article/2009/07/ 08/AR2009070800030.html (last visited Apr. 9, 2010). 
However, should that strategy fall short, the President should forge ahead by choosing from among the most politically viable smaller bills and proposals that seek to protect the most vulnerable noncitizens. To pick but one example, it is time that the country passed the DREAM Act. Originally introduced in 2001, the Development, Relief and Education for Alien Minors (DREAM) Act provides a pathway to citizenship for undocumented high school graduates who choose to attend college or serve in the military. Thanks to the Supreme Court's decision in Plyler v. Doe, ${ }^{126}$ approximately 65,000 undocumented students graduate from the nation's high schools each year; unfortunately, most are unable to continue their education due to their ineligibility for government aid owing to their lack of status. Moreover, many of these students were not aware of their undocumented status until they applied for college because they came to America as preschool children or infants, growing up having always assumed they were U.S. citizens.

Consistent with the Christian realist perspective advocated here, the DREAM Act extends hospitality to the stranger while working within the constraints of a politics insistent on obeisance to the rule of law and reluctant to grant "amnesty" to all 12 million for fear of undermining order. Similar bills calling for guest-worker programs ${ }^{127}$ and status for domestic partners of U.S. citizens ${ }^{128}$ also present viable opportunities to practice biblical principles of hospitality within the constraints of the existing legal and political regime.

\section{Reaching Out Toward the City of God: CHRISTIAN IDEALS AND OPEn Borders}

One might argue that the Christian realist view that I outline above is too Christian and not realistic enough. Indeed, the critic might go on further to state that Obama's current approach (or indeed, President Bush's-after all, he is a Christian, too) is more in line with Christian realist thought than mine. Protecting our borders and conserving resources for our citizens first both demonstrate good stewardship of our limited gifts, so the argument goes. ${ }^{129}$ These are all fair comments and certainly consistent with the belief that any idea, especially that proffered by a Christian realist, may be incorrect, given mankind's fallibility.

126. Plyler v. Doe, 457 U.S. 202 (1982). On Plyler, undocumented persons, and the DREAM Act, see also Hiroshi Motomura, Immigration Outside the Law, 108 Colum. L. Rev. 2037 (2008); Michael A. Olivas, IIRIRA, The DREAM Act, and Undocumented Student College Residency, 30 J.C. \& U.L. 435 (2004).

127. See, e.g., Agricultural Job Opportunities, Benefits and Security Act of 2009 ("AgJOBS"), S. 1038 and H.R. 2414, 111th Cong. (1st Sess. 2009).

128. Uniting American Families Act of 2009, S. 424, 111th Cong. (1st Sess. 2009).

129. James Edwards argues that the Bible recognizes special obligations to one's family, community, and nation that support this perspective. Edwards, supra note 7, at 55-57. 
Still, I cannot help but think that even the proposals discussed in the last section border on the earthly compromise that Bonhoeffer warned against. To be true to political reality requires that one accept the world as it is-comprised of nation-states, each seeking to monitor its borders, to varying degrees. Yet, the Christian in me believes that there should be space to explore a world beyond borders, if not in a utopian sense, at least in a fashion more consistent with Jesus's call to radical love and hospitality to the stranger. As Paul reminds the Galatians, there are no borders in Christ's eyes: "There is neither Jew nor Greek, slave nor free, male nor female, for you are all one in Christ Jesus." 130 This suggests to me that borders are more the product of man's actions than of God's. ${ }^{131}$ Nonetheless, it may well be that open borders advocates tend to highlight the "Christian" in "Christian realism" while downplaying the reality that securing borders through enforcement is a necessity other Christians believe needs to be taken seriously.

While advocating for completely open borders ${ }^{132}$ at present would be to abandon realism, Christians interested in immigration reform should seriously consider drastic paradigm shifts as alternatives to piecemeal solutions, no matter how comprehensive. For example, Dean Kevin Johnson argues that U.S. immigration policy should rethink its basic approach to noncitizen admissions. Instead of strictly scrutinizing each applicant who comes to visit or reside permanently in the United States, the government should presume instead that all are eligible to come for as long as they like, except if they present a true threat to the country and its people, as a terrorist or a criminal surely would. ${ }^{133}$ Such a proposal would push the limits of our thinking with regards to Christian hospitality and yet would simplify our byzantine immigration process considerably, as we would now have to focus our attention simply on those who would be true threats to our democracy.

To my knowledge, this proposal has not received the sustained popular attention it deserves, though it has been very well received within academia. Perhaps it would be pure fantasy to expect otherwise, but a President who was willing to seriously consider a complete overhaul of the very foundation of our immigration regime may be the closest to a prophetic witness that we may get to see.

130. Galatians 3:28 (New International Version).

131. Even the diaspora following the fall of the Tower of Babel might be attributed to man's arrogance and desire to be like God rather than to God's wish that there be many disparate nations and cultures on the earth. See Genesis 11:1-9 (New International Version).

132. E.g., Joseph H. Carens, Aliens and Citizens: The Case for Open Borders, 49 Rev. OF Pol. 251 (1987); Roger Nett, The Civil Right We Are Not Ready for: The Right of Free Movement of People on the Face of the Earth, 81 Ethics 212 (1971).

133. Kevin R. Johnson, Opening the Floodgates: Why America Needs to Rethink Its BORDERS AND IMMIGRạtion LAWS 196-99 (2007). 